\title{
Agroecological modeling of spring barley cultivation technology in the conditions of the Penza region
}

\author{
Aleksey Buzylev*, Mariya Tihonova, Evgeniy Taller and Ivan Vasenev.
}

Russian State Agrarian University - Moscow Timiryazev Agricultural Academy, Moscow, Russia

\begin{abstract}
The article presents the results of modeling the cultivation of barley of the Eifel variety on leached chernozems of the Bashmakovsky district of the Penza region. In order to carry out modeling, the framework Local information and reference system for the optimization of land use was deeply adapted. The adaptation of the software modules to the climatic and soil conditions of a particular study area allowed one to reach 7\% errors in modeling the cultivation of agricultural crops in the presence of a set of indicators necessary for constructing a model. Technological calculations of the model made it possible to reduce the number of minimum required technological operations, as well as to rationally distribute the application of mineral fertilizers for the planned yield. The economic calculations of the model made it possible to achieve a high production profitability of $66 \pm 7 \%$. The constructed model was tested on the experimental field of «Bashmakovskiy khleb» JSC in 2020. Practical verification has shown the possibility of using the model in agricultural production under normal climatic conditions and its high correlation with the actual results obtained [1]. Statistical analysis of the calculated data of the model and the actual yield with the achieved economic indicators in the conditions of the model field showed a level of reliability of calculations of $95 \%$.
\end{abstract}

\section{Introduction}

In connection with the policy of the developed "green standards" adopted and developed in the territory of the Russian Federation, there is an urgent need to adapt existing technologies for the cultivation of agricultural crops to the requirements of greening crop production. The purpose of these standards is to increase the level of confidence in the certification of ecological products, popularize environmentally friendly goods and production methods and, as a result, increase the demand for environmentally friendly innovative products, services and technologies.

Crop technologies currently used by leading agricultural producers are most often based on an adaptive landscape approach without taking into account the ecological component of the quality of the soil cover and is often based on an outdated system of "programming the yield" with the calculation of doses of the main nutrients for a given crop, without taking into account the aftereffect already applied mineral and organic fertilizers, as well as the removal of accumulated macronutrients with the harvest and their partial return when plowing crop residues. Achieving the level of truly ecologically high-quality "green" products is also impossible without the availability of basic information about the actual agroecological quality of the soils on which it is planned to obtain these products [2].

The model proposed for use, included in the Local information and reference system for optimizing farming in the farm, allows you to flexibly configure the calculation of a full set of indicators when modeling the cultivation of a specific agricultural crop based on its varietal agroecological passport, taking into account the needs of a particular variety for climatic and soil characteristics.

\section{Experimental}

A highly cultivated experimental field located in the Bashmakovsky district of the Penza region on the territory of JSC «Bashmakovskiy khleb» was used as a model. The field area is 120 hectares, of which 100 hectares are divided into a regular 100-meter survey grid. The soils are represented by leached powerful humus non-eroded clayey chernozem.

The field is the top of a flat watershed hill (Figure 01) with gentle slopes of $2-4^{\circ}$ for all exposures. The prevailing exposure is northwest. The microrelief is represented by the forms of suffusion processes - saucers and depressions [3].

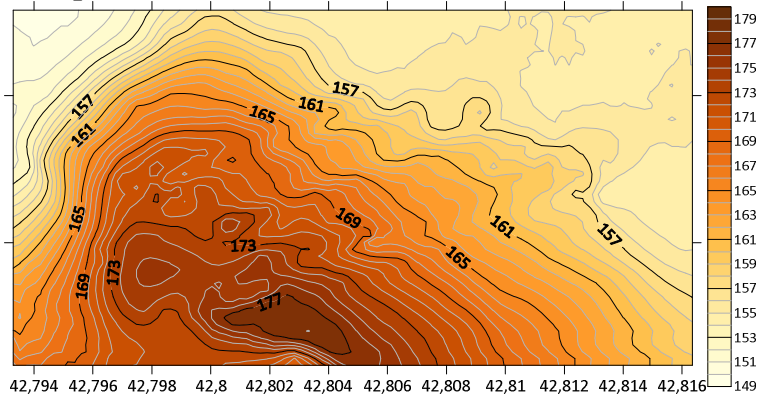

Figure 01. Digital elevation model of the experimental field

\footnotetext{
* Corresponding author: axe@rgau-msha.ru
} 
The grouping of the soils of the model field by the content of nutrients, carried out within the framework of its agroecological assessment, is presented in Table 01 .

Table 01. Grouping of model field soils by nutrient content

\begin{tabular}{|c|c|c|c|c|}
\hline $\min$ & $\max$ & Fertility & Amount, ha & $\%$ \\
\hline \multicolumn{6}{|c|}{ Nitrogen, $\mathrm{mg} / \mathrm{kg}$ (according to the Cornfield method) } \\
\hline 101 & 150 & low & 75 & 75 \\
\hline 151 & 200 & average & 15 & 15 \\
\hline \multicolumn{6}{|c|}{ Exchangeable potassium mg/kg (GOST 26204-91) } \\
\hline 81 & 120 & increased & 71 & 71 \\
\hline 121 & 180 & high & 29 & 29 \\
\hline \multicolumn{5}{|c|}{ Mobile phosphorus, mg/kg (GOST 26204-91) } \\
\hline 101 & 150 & increased & 32 & 32 \\
\hline 151 & 200 & high & 68 & 68 \\
\hline \multicolumn{5}{|c|}{ Humus, mg/kg (GOST 26213-91) } \\
\hline 6.1 & 8.0 & increased & 98 & 98 \\
\hline 8.1 & 10 & high & 2 & 2 \\
\hline
\end{tabular}

The leached chernozems of the model field showed a low nitrogen content, which, in our opinion, is associated with the high-intensity farming system used on the farm and is typical of such soils in the Penza region. The content of phosphorus and potassium is estimated as high on average. Also, an increased humus content may indicate the presence of a positive balance of nutrients and the absence of obvious degradation processes in the soil cover.

The exchangeable acidity of the plow horizon $(\mathrm{pH})$ was determined by the potentiometric method and varied in the range from 4.6 to 5.0, which characterizes the soil as moderately acidic. The hydrolytic acidity of the plow horizon was $6.8 \mathrm{ppm}$, the amount of absorbed bases was $32.5 \mathrm{ppm}$ with a degree of base saturation of $82.6 \%$. The average content of calcium and magnesium is determined at the level of 24.0: $3.8 \mathrm{ppm}$.

The content of trace elements and heavy metals in the arable horizon of the soil is presented in Table 02 .

Table 02. Content of microelements and heavy metals, $\mathrm{mg} / \mathrm{kg}$

\begin{tabular}{|c|c|c|c|c|}
\hline $\mathrm{S}$ & $\mathrm{B}$ & $\mathrm{Cu}$ & $\mathrm{Zn}$ & $\mathrm{Mo}$ \\
\hline 4.9 & 2.3 & 0.1 & 0.3 & 0.1 \\
\hline $\mathrm{Pb}$ & $\mathrm{Cd}$ & $\mathrm{Hg}$ & $\mathrm{Ni}$ & $\mathrm{As}$ \\
\hline 13.1 & $0 / 3$ & 0.0 & 0.1 & 2.2 \\
\hline
\end{tabular}

The agroecological assessment of the experimental field showed that there was no excess of the maximum permissible concentrations of heavy metals in the arable horizon. Soil-ecological quality (SAB) was estimated at 72 points.

Spring barley (Hordeum vulgare L.) variety nutans, variety EIFEL ${ }^{\circledR}$, SECOBRA Recherches, France was used as a modeled object. The maximum yield of this barley was achieved during the State tests in the Kursk region and amounted to $77.1 \mathrm{cwt} / \mathrm{ha}$. The variety is characterized as an intensive type with high resistance to drought, disease and stress conditions.

The direction of use of this variety is brewing (low protein content, high extractability).

The growing season of the culture of 70-80 days allows its cultivation in the conditions of the Penza region $[4,5]$. The variety is resistant to lodging, which is relevant for the conditions of the model field. The choice of varieties, as well as the distribution of sown areas in the structure of crop rotation, now very much depends on the potential customer, and in this case, the variety was recommended for cultivation by the largest customer of malting barley in the region.

The modeling was carried out on the basis of an adapted and regionalized version of the DSS of the Local information and reference system for optimizing agriculture in the farm, developed under the guidance of Professor I Vasenev. The software package is designed to provide information support for management decisions to optimize the placement of crops and varieties, to develop the dynamics of the crop rotation structure, taking into account the agroecological characteristics of lands, the technical and economic capabilities of the economy, as well as climatic and price forecasts. In the process of modeling, an assessment of technological costs is carried out with the calculation of the profitability of agricultural production in a specific field. Separately, the optimization of techniques and methods of soil cultivation and the application of fertilizers and plant protection products during the growing season of the crop is carried out.

The initial DSS data are taken from the initially filled in databases, which are formed and saturated on the basis of operational information of the results of soil research, as well as regulatory information from zoned methodological guidelines. Part of the normative data is contained in the model in the form of arrays of constants or is entered by the model operator at the request of the program. DSS has an open framework architecture, which allows you to correct the model «on the fly», as well as significantly modernize the entire DSS complex.

\section{Result and discussion}

The DSS was adapted to the agroclimatic conditions of the model field based on the calculation of the average values of the required parameters of the model using open archived data from meteoinfo.ru and rp5.ru. These platforms provide an opportunity to receive an archive of meteorological observations with a discreteness of taking readings 3-4 times a day. The indicators were calculated using the STATISTICA program based on data for 10 years of the previous modeling year, allowing to achieve minimum deviations in subsequent calculations, taking into account the trends of global climate change. The final values of the sum of active temperatures turned out to be higher than the accepted average statistical data for the Penza region, and the amount of precipitation by months is slightly lower than the accepted statistics with a redirection of their distribution to the autumn-winter period from the winter-spring period (Figure 02). 


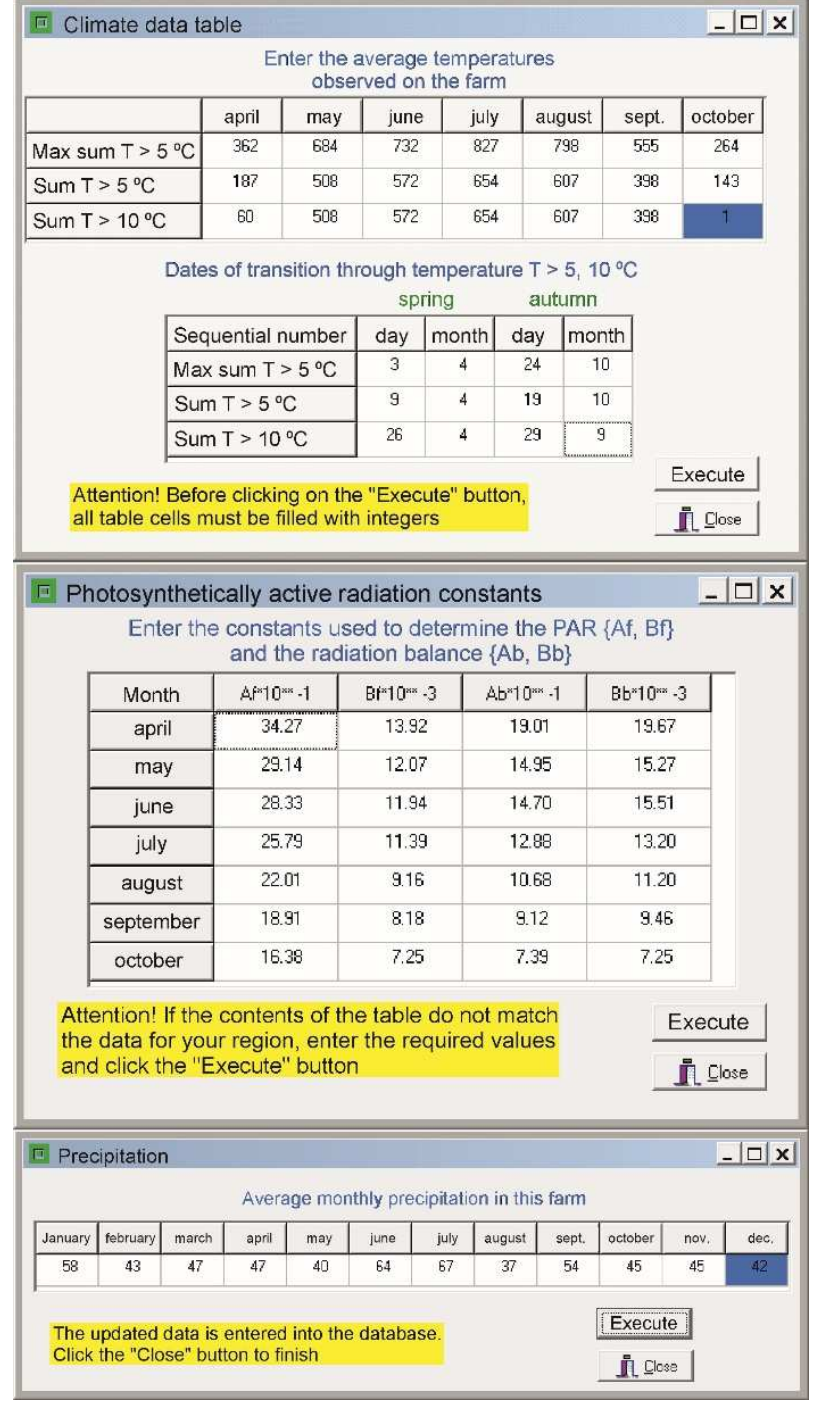

Figure 02. Modules of the climatic database of the agroecological characteristics of the object

Filling in the parameters of the simulated barley, such as calorie content, the sum of the parts of the main and by-products, standard moisture content and water consumption coefficient, was made based on the data of its agroecological passport from the State Register of Breeding Achievements. The calculated rates of return on the use of mineral fertilizers on leached chernozems were set at the level: $\mathrm{N}-0.45, \mathrm{P}-0.26, \mathrm{~K}-0.25$. The payback coefficients for the average fertility level corresponding to the current characteristics of the model field were set at the level: $\mathrm{N}-0.48, \mathrm{P}-1.3, \mathrm{~K}-1.43$. The coefficients of using NPK from organic and mineral fertilizers by years, as well as their removal with the harvest, were introduced according to the recommendations developed in 2000 at the All-Russian Research Institute of Agriculture and Post Erosion Protection.

Soil data of the model field (Figure 03) were entered into the agroecological passport and included metric parameters for calculating economic costs and average soil parameters for ecological modeling and adaptation of agricultural technologies. The base of the agroecological passport also includes the history of the field according to the applied rotation and yield of agricultural crops, as well as the dose of applied organic, mineral fertilizers and ameliorants [6].

\begin{tabular}{|c|c|c|c|c|c|c|c|c|c|c|c|}
\hline \multicolumn{9}{|c|}{ [ Preview options selected field } & \multirow[b]{2}{*}{ - clays } & \multirow[t]{2}{*}{ 口 } & \multirow[t]{2}{*}{$x$} \\
\hline \multicolumn{9}{|c|}{$\begin{array}{l}\text { To view the selected field parameters - ШП-19 } \\
\text { Filling year - } 2020 \text {. Soil type - leached chernozems. } \\
\text { The degree of erosion is non-eroded. Mechanical composition - clays }\end{array}$} & & & \\
\hline \multirow{2}{*}{\multicolumn{3}{|c|}{$\begin{array}{l}\text { Field metric cha } \\
\text { Name }\end{array}$}} & racterist & & & \multicolumn{5}{|c|}{ Average soil parameters } & \\
\hline & & & \multicolumn{2}{|c|}{ bimension } & Values & & Name & & Dimension & Values & ^ \\
\hline \multicolumn{3}{|c|}{ Field area } & \multicolumn{2}{|c|}{ ha } & 100 & \multicolumn{3}{|c|}{ Acidity (saline $p H$ ) } & $\mathrm{pH}$ & 4.7 & \\
\hline \multicolumn{3}{|c|}{ Driving length of the field } & \multicolumn{2}{|c|}{$\mathrm{km}$} & 0,5 & \multicolumn{3}{|c|}{ Hydrolytic acidity } & $\mathrm{ppm}$ & 6.8 & \\
\hline \multicolumn{3}{|c|}{ Distance of fuel depot } & \multicolumn{2}{|c|}{$\mathrm{km}$} & 21 & \multicolumn{3}{|c|}{ Humus content } & $x$ & 8.4 & \\
\hline \multicolumn{3}{|c|}{ Distance warehouse havest } & \multicolumn{2}{|c|}{$\mathrm{km}$} & 23 & \multicolumn{3}{|c|}{ Humus horizon } & sm & 87 & \\
\hline \multicolumn{3}{|c|}{ Distance ff. fertilizer storage } & \multicolumn{2}{|c|}{$\mathrm{km}$} & 21 & \multicolumn{3}{|c|}{ Phosphorus content } & $\mathrm{mg} / 100 \mathrm{~g}$ & 103.3 & \\
\hline \multicolumn{3}{|c|}{ The steepness of the slope } & \multicolumn{2}{|c|}{ degrees } & 2 & \multicolumn{3}{|c|}{ Potassium content } & $\mathrm{mg} / 100 \mathrm{~g}$ & 198.2 & \\
\hline Soil de & & & $g / c$ & & 1.28 & Nitrogen & $n$ content & & $\mathrm{mg} / 100 \mathrm{~g}$ & 121.8 & \\
\hline Slope $\mathrm{E}$ & posure & & . & & southem & Sum of & absorbed & bases & $\mathrm{ppm}$ & 27.8 & v \\
\hline & ertilizer applic. & ation ra & ates by & ears (fo & for 10 year & & & Field his & ory for $10 \mathrm{ye}$ & & \\
\hline Year & organic tha & lime & tha & N tha & & Ptha A & Year & & & Yield & ^ \\
\hline 2020 & 0 & 0 & & 0 & & 0 & 2020 & & & 55.93 & \\
\hline 2019 & 0 & a & & 105 & & 32 & 2019 & Winte & wheat & 35.47 & \\
\hline 2018 & 0 & a & & 0 & & 0 & 2018 & Pure & fallow & & $\checkmark$ \\
\hline 2017 & 0 & a & & 66 & & 20 & If the fie & Id view I & completed & $X$ Canc & \\
\hline 2016 & 0.2 & 0 & & 113 & & $39 \quad$ V & & & & & \\
\hline$<$ & & & & & & , & & & nemic calc & & \\
\hline
\end{tabular}

Figure 03. Agroecological passport of the simulated field

The process of modeling the cultivation of barley was carried out in stages with a set of complex tasks:

1. Field selection, indication of the predecessor and predecessor - predecessor, selection of the simulated crop from the compiled database and calculation of its potential yield on the model field, taking into account the full range of agroecological characteristics and limiting soil conditions. The potential yield of Eiffel barley, provided by the arrival of Photosynthetically Active Radiation, was $93.72 \mathrm{cwt} / \mathrm{ha}$; provided with productive moisture - $30.27 \mathrm{cwt} / \mathrm{ha}$; provided with the arrival of PAR, agro-climatic and agro-ecological conditions $65.17 \mathrm{cwt} / \mathrm{ha}[7,8]$. Considering the significant lack of productive moisture in the model field, further calculations were carried out for the average potential yield according to the data of the State Variety Tests, which amounted to $55 \mathrm{cwt} / \mathrm{ha}$.

2. Calculation of the need for fertilizers for the planned yield, taking into account the correction factors for the agroecological state of the model field with an intensive environmentally friendly farming system, showed the need to apply $155 \mathrm{~kg} / \mathrm{ha}$ of nitrogen and 41 $\mathrm{kg} / \mathrm{ha}$ of phosphorus fertilizers based on the active ingredient. According to the simulation results, there was no need to apply potash fertilizers.

When distributing fertilizer application doses, the model takes into account the plowing of crop residues of the predecessor crop in the amount of $0.1 \mathrm{t} / \mathrm{ha}$, which immediately plays into a positive balance of nutrients [9]. The application of the required amount of fertilizers into the development phases was also distributed using the expert method, and, based on the technological equipment of a particular manufacturer of agricultural products; the forms and type of mineral fertilizers were selected.

The model calculated the need for pre-sowing application of ammonium nitrate in the amount of 100 $\mathrm{kg} / \mathrm{ha}$. Sowing according to the DSS recommendation should be carried out with simultaneous subsoil application of sulfoammophos in an amount of 150 
$\mathrm{kg} / \mathrm{ha}$. More during the growing season, feeding crops are not required [9].

At a given selling price of finished products of 140 a/ton, the economic effect from the use of fertilizers in the total estimated amount of $250 \mathrm{~kg} / \mathrm{ha}$ was 77018.8 $7484.1=69534.7$ a.

In the current version of the DSS, the Chemical Fertilizer Supplier Recommendations Module was launched in test mode, which makes it possible to select the optimal fertilizer manufacturer for reasons of price / environmental friendliness. This function was tested for the first time and the result was obtained only for phosphorus fertilizers. When specifying the search for the most environmentally friendly fertilizers, DSS suggested using sulfoammophos PhosAgro according to the criterion of the minimum cadmium content at $5 \%$, indicating that for other manufacturers this indicator ranges from 7.5 to $15 \%$.

3. An express analysis of the minimum required costs for growing a crop on a model field made it possible to select the main technological operations and calculate the cost of their application, which amounted to 155992 a on a field of 100 hectares (Figure 04).

\begin{tabular}{|c|c|c|c|c|c|}
\hline \multicolumn{4}{|l|}{ (1) Calculation of costs by field } & & \\
\hline \multicolumn{6}{|c|}{$\begin{array}{c}\text { The task of calculating technological costs for the field wiा-19 } \\
\text { with a total area of } 100 \text { hectares is being performed }\end{array}$} \\
\hline \multicolumn{6}{|c|}{$\begin{array}{l}\text { Soil-saving machine technology for the cultivation of spring grain crops } \\
\text { (the predecessor is sugar beet, corn, cereals) }\end{array}$} \\
\hline Sequential number & Apply & \begin{tabular}{l|l|} 
Production \\
in 1 hour, ha
\end{tabular} & \begin{tabular}{|c|} 
Labor costs per \\
1 ha, man-hour
\end{tabular} & \begin{tabular}{|c|c|}
$\begin{array}{c}\text { Fuel consumption } \\
\text { per } 1 \text { ha, iters }\end{array}$ \\
\end{tabular} & $\begin{array}{c}\text { Field operation } \\
\text { costs, } p\end{array}$ \\
\hline Stubble plowing (disking) & $\nabla$ & 226 & 0.44 & 737 & 375210 \\
\hline Moldboardless tier tillage & $\nabla$ & 4.13 & 0.24 & 1550 & 583500 \\
\hline Slotting fall plowing across the slope & $\square$ & 4.10 & 0.24 & $6 \pi$ & on \\
\hline Snow retention & $\square$ & 5.60 & 0.18 & 297 & 0.0 \\
\hline Closing moisture in spring & $\nabla$ & 8.40 & 012 & 330 & 144500 \\
\hline Presowing cultivation & $\nabla$ & 6.70 & 0.12 & 270 & 12510.0 \\
\hline Sowing with fertilization & $\nabla$ & 4.91 & 0.40 & 480 & 278400 \\
\hline Top dressing of crops & $\sqrt{8}$ & 10.50 & 0.10 & 0.67 & 5910 \\
\hline \multicolumn{6}{|c|}{ The total costs for the selected technology for a given field were - $155922.0 \mathrm{P}$} \\
\hline Spring crops by predecessors & & 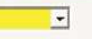 & OK & & \multirow{2}{*}{ Il close } \\
\hline Enter the price $P$ per man-hour 3300 & of fuel & & Execute & & \\
\hline
\end{tabular}

Figure 04. Proposed DSS technology for cultivation of barley on the model field

4. The general technology of barley cultivation and calculations of economic costs in the field were carried out according to the average market (according to Yandex.market 04.2019) cost of seeds, final products, fertilizers and plant protection products.

On the basis of the set of agricultural machinery and units available on the farm added to the database, DSS has proposed a resource-saving crop cultivation technology (Figure 05).

\begin{tabular}{|c|c|c|c|c|c|c|c|c|}
\hline \multicolumn{4}{|c|}{ Basic technology of cultivation of agricultural crops } & & & & - & $\times$ \\
\hline \multicolumn{9}{|c|}{ Selection menu for viewing and adjusting standard crop cultivation technologies } \\
\hline Considered parameters & \multirow{2}{*}{$\begin{array}{l}\text { Optimal } \\
\text { timing }\end{array}$} & \multicolumn{2}{|c|}{ Technical means } & \multirow{2}{*}{$\begin{array}{l}\text { Conven- } \\
\text { tional ha }\end{array}$} & \multirow{2}{*}{\multicolumn{2}{|c|}{ Staff, persons }} & \multirow{2}{*}{\multicolumn{2}{|c|}{$\begin{array}{l}\text { Labor costs per } \\
1 \text { ha, man-hour } \\
\text { operator wor }\end{array}$}} \\
\hline Technological operations & & main 1 & trailed & & & & & \\
\hline 1. Plowing to a depth of $20-22 \mathrm{~cm}$ & 25070715000 & K.7.00a & J0:2430 & 1.35 & 1 & 0 & 0.76 & $c^{2}$ \\
\hline 2. Early spring harrowing & 300031004 & J0.5155M & j0.2635 & 0.11 & 1 & 0 & 0.13 & c \\
\hline 3. Loading of mineral fertilizers & $14 / 04-30004$ & Komos & Mesitou & 03 & 1 & 1 & 0.14 & 0.1 \\
\hline 4. Application of mineral fertilizers & $14 / 04300 / 04$ & 6en892 & G:224 & 0.18 & 1 & 0 & 0.34 & c \\
\hline 5. Seed dressing & $14 / 04-15 / 04$ & . & nc.20m & 0.05 & 0 & 1 & 0 & a \\
\hline 6. Delivery of seeds, fertilizers & $14004-3004$ & Konss & Mositau & 0.06 & 1 & 2 & a. & a \\
\hline 7. Sowing with row fertilizer $N, P$ & $14 / 0430004$ & J0:5128M & J0.0837 & 0.20 & 1 & 1 & 0.3 & 0 \\
\hline 8. Supply of water (solution) & $25 / 105 \cdot 31 / 05$ & ГАЗАU & & 0.06 & 1 & 0 & 0.5 & c \\
\hline 9. Crop treatment with pesticides & $25 / 105 \cdot 31 / 05$ & MT3 & aC.3450 & 0.17 & 1 & 1 & 0.22 & 0. \\
\hline 10. Supply of water (solution) & $2306-30006$ & TA3AU & & 0.06 & 1 & 0 & 0.5 & c \\
\hline 11. Crop treatment with pesticides & $2306-3006$ & MAE 4240 & & a.17 & 1 & 1 & 0.22 & $0:$ \\
\hline \begin{tabular}{|l|l|} 
12. Direct harvesting \\
\&
\end{tabular} & 07/08-20103 & JD.5760 & . & 214 & 1 & 1 & 0.78 & aiv \\
\hline & & & Transt: & ata for & ulations & Print & & Cancel \\
\hline
\end{tabular}

Figure 05. Proposed DSS technology for cultivation of barley on the model field

The summary table of costs, built using the simulated technology in automatic mode, showed a profit from the field of $2782000 \mathbf{\square}$ with a profit per hectare of $7800 \mathbf{\square}$. The profitability of production, excluding the cost of transportation, cleaning, drying and storage of grain before sale, ranged from 59.4 to $72.9 \%$ and mainly depended on the cost characteristics of fertilizers and plant protection products at an optimal level of yield. With an increase or decrease in the yield of the simulated crop, the profitability decreased proportionally and when the potential yield of $65.17 \mathrm{cwt} / \mathrm{ha}$ was reached, it was equal to $0 \%$.

\section{Conclusion}

Modeling, carried out with the use of an adapted framework DSS for the optimization of agriculture, made it possible to calculate the potential yield of spring barley of the EIFEL variety on a model field and, on the basis of the data obtained, draw up a resource-saving technology for cultivating an agricultural crop. The fullscale application of this technology for the planned yield confirmed the accuracy of calculations with a yield of $55.93 \mathrm{cwt} / \mathrm{ha}$ obtained in 2020, which made it possible to reach a profitability of agricultural production comparable to the predicted model and amounted to $42 \%$. The deviation of the calculated profitability from the actual one was associated with an increase in the cost of mineral fertilizers and plant protection products, as well as with a decrease in the cost of final products in the grain market relative to that laid down in the model. When adjusting the modeling data for the final price indicators based on the results of approbation, it was possible to establish the level of reliability of calculations at $95 \%$.

The results obtained allow us to speak about the expediency of using this model by end agricultural producers and the need for its development on a wide range of agricultural crops cultivated on the territory of the model farm for further testing and verification.

\section{Acknowledgments}

We are grateful to the Scientific Center of the World Level "Agrotechnology of the Future" specializing in the direction "Research and development of new selflearning intelligent Decision Support Systems for agroecological optimization of adaptive farming systems".

\section{References}

1. V.P. Samsonova, J.L. Meshalkina, Y.N. Blagoveschensky, A.M. Yaroslavtsev, J.J. Stoorvogel, Prec. Agric., 19(6), 1085-1099 (2018) 
2. O.A. Savoskina, S.I. Chebanenko, Z.K. Kurbanova, A.V. Shitikova, N.A. Kudryavtsev, IOP, 579(1), 012-055 (2020)

3. V.I. Vasenev, M.V.Slukovskaya, Z. Cheng, ... D.D. Gosse, E.A. Dovletyarova, JEQ, 50(1), 6377 (2021)

4. A. Di Paola, L. Caporaso, F. Di Paola, ... S. Castaldi, R. Valentini, Land Use Policy, 78, 7077 (2018)

5. I. Vasenev, I. Andreeva, E. Koshkin, M. Samardžić, SGEM, 17(43), 725-732 (2017)

6. P.M. Dokuchaev, J.L. Meshalkina, A.M. Yaroslavtsev, IOP, 107(1), 012-113 (2018)

7. A.O. Ragimov, M.A. Mazirov, E.M. Shenterova, O.A. Savoskina, V.D. Polin, IOP, 670(1), 012037 (2121)

8. I.M. Yashin, ESS, 35, (SUPPL. 1, 2002)

9. I.O. Korvigo, E.V. Pershina, E.A. Ivanova, ... N.A. Provorov, E.E. Andronov, Microbiology (RF), 85(2), 231-242 (2016) 